University of Massachusetts Amherst

ScholarWorks@UMass Amherst

2020

\title{
STEM degree completion and first-generation college students. A cumulative disadvantage approach to the outcomes gap
}

\author{
Genia Bettencourt \\ University of Massachusetts Amherst \\ Catherine A. Manly \\ University of Massachusetts Amherst \\ Ezekiel Kimball \\ University of Massachusetts Amherst \\ Ryan Wells \\ University of Massachusetts Amherst
}

Follow this and additional works at: https://scholarworks.umass.edu/cfssr_publishedwork

Part of the Higher Education Commons

\section{Recommended Citation \\ Bettencourt, Genia; Manly, Catherine A.; Kimball, Ezekiel; and Wells, Ryan, "STEM degree completion and first-generation college students. A cumulative disadvantage approach to the outcomes gap" (2020). Review of Higher Education. 35. \\ Retrieved from https://scholarworks.umass.edu/cfssr_publishedwork/35}

This Article is brought to you for free and open access by the Center for Student Success Research at ScholarWorks@UMass Amherst. It has been accepted for inclusion in Published Work by an authorized administrator of ScholarWorks@UMass Amherst. For more information, please contact scholarworks@library.umass.edu. 
STEM degree completion and first-generation college students: A cumulative disadvantage approach to the outcomes gap

\author{
Genia M. Bettencourt a \\ Catherine A. Manly \\ Ezekiel Kimball \\ Ryan S. Wells \\ PRE-PRINT VERSION
}

For published version, please see:

Bettencourt, G. M., Manly, C. A., Kimball, E., \& Wells, R. S. (2020). STEM degree completion and first-generation college students. A cumulative disadvantage approach to the outcomes gap. Review of Higher Education, 43(3), 753-779. 


\begin{abstract}
STEM majors offer pathways to lucrative careers but are often inaccessible to first-generation students. Using data from the Education Longitudinal Study, we conducted descriptive statistics, regression analyses, and group comparisons to examine differences between first-generation students and continuing-generation students across STEM degree, non-STEM degree, dropout, and no degree completion. Findings illuminate that generation status is related to STEM completion, but other factors are driving this association; for example, pre-college STEM factors have significant predictive power. Our implications suggest a need to further examine precollege and transfer pathways to STEM and to explore the limitations of first-generation status as a categorization.
\end{abstract}

Keywords: first-generation, STEM, persistence, cumulative disadvantage 


\section{Introduction}

STEM degrees have long been touted as a pathway to lucrative careers (c.f., Bush, 1945; National Science Foundation [NSF], 2015a), an idea supported by empirical evidence (Melguizo \& Wolniak, 2012; Xu, 2013). However, research findings also suggest that access to STEMrelated outcomes is stratified by student characteristics, with students from minoritized populations less likely to be STEM participants or completers than their peers (e.g., Chang, Sharkness, Hurtado, \& Newman, 2014; Gayles \& Ampaw, 2011; NSF, 2015b). One minoritized population experiencing these challenges within STEM is first-generation students (Dika \& D’Amico, 2015), a population that represents one-third of the students enrolled in U.S. postsecondary institutions (Skomsvold, 2015).

While recent scholarship has focused on the intersection of first-generation status and STEM participation or completion (e.g., Crisp, Nora, \& Taggart, 2009; Dika \& D’Amico, 2015), these studies were limited to single institutional contexts. Additional work is needed to clarify where the STEM outcomes of first-generation college students differ from their continuinggeneration peers across institutional types and to identify the underlying explanatory factors. This work is critical because studies of first-generation college students suggest that their pathways differ from continuing-generation college students in important ways (Pascarella, Pierson, Wolniak, \& Terenzini, 2004). Statistically, first-generation students have divergent demographics, precollege trajectories, and within-college experiences. These differences_-along with the fact that first-generation college students are disproportionately more likely to attend two-year or nonselective institutions (Cataldi, Bennett, \& Chen, 2018) - account for variance in a wide-range of college outcomes (Pascarella et al., 2004). 
However, many foundational studies on first-generation persistence rely on now outdated data (Ishitani, 2006; McCarron \& Inkelas, 2006; Pascarella et al., 2004; Terenzini, Springer, Yaeger, Pascarella \& Nora, 1996). Updated empirical work is needed to inform evidence-based interventions that can lead to greater STEM degree completion for first-generation college students, a key step in emerging STEM career trajectories. These evidence-based interventions are critical to addressing the President's Council on Advisors on Science and Technology (PCAST) (2012) concern that the United States will need to increase STEM completion by $34 \%$ annually to meet its goal of 1 million degrees over the next decade. Since majoring in STEM can also lead to important long-term outcomes for individual students, such as future earnings (Melguizo \& Wolniak, 2012), understanding the factors that lead to degree completion serves as both a matter of national benefit and social justice.

\section{Literature Review}

To understand how first-generation students persist and complete degrees within STEM fields, we drew upon two bodies of literature. The first explored factors that traditionally influenced the postsecondary experiences of first-generation students. The second examined factors that lead to STEM persistence and degree completion, including the impact of demographic characteristics.

\section{First-generation Student Persistence and Completion}

The most prevalent definitions of first-generation status include a) students whose parents have no postsecondary education (Ishitani, 2006; Padgett, Johnson, \& Pascarella, 2012), or b) some postsecondary education without a degree (Pike \& Kuh, 2005). Across both categorizations, research consistently demonstrated that first-generation students received limited anticipatory socialization related to college-going and within-college experiences when 
compared to their continuing-generation peers (Engle, Bermeo, \& O'Brien, 2006). Additionally, first-generation college students disproportionately identified from marginalized racial and ethnic groups and low-income backgrounds (Lohfink \& Paulsen, 2005; Pascarella et al., 2004). Consequently, first-generation students experienced higher risks of leaving postsecondary education than continuing-generation peers (Ishitani, 2006). Over half of first-generation students $(62.1 \%)$ have not achieved their original educational aspirations eight years after high school (McCarron \& Inkelas, 2006). These results show that regardless of how the term firstgeneration is operationalized, as a whole this group attended, persisted, and completed at lower rates than their continuing-generation peers.

While the postsecondary outcomes for first-generation college students have been quite clear, the underlying structural explanations for these outcomes have not. First-generation students experienced numerous barriers on campus even after consideration of pre-college characteristics (Aspelmeier, Love, McGill, Elliott, \& Pierce, 2012; Pascarella et al., 2004). These barriers included higher numbers of hours worked, lower extracurricular involvement, and fewer completed credit hours (Pascarella et al., 2004). While student-faculty interaction has an equal impact on first- and continuing-generation students, the former were far less likely to interact with faculty outside of class, through for-credit research projects, over email, or in-person (Kim $\&$ Sax, 2009). The limited academic and social integration of first-generation college students has also been shown to predict non-completion (Lohfink \& Paulsen, 2005). It has been evident that within-college experiences shape postsecondary outcomes for first-generation college students, but more research is warranted to determine exactly why that is the case.

The empirical literature focused specifically on the STEM experiences of first-generation college students is limited; however, the available literature base shows that first-generation 
college students participate in and experience STEM pathways differently than their continuinggeneration peers. For example, first-generation college students enrolled in STEM fields at lower rates than their continuing-generation peers (National Center for Education Statistics [NCES], 2009) and had a stronger intention to leave before degree completion (Xu, 2016). Early academic performance, as measured through first semester grade point average (GPA), has been shown to predict persistence in STEM for first-generation college students (Dika \& D'Amico, 2016). Moreover, while math preparation was predictive specifically for first-generation students in physical sciences, engineering, math, and computer sciences (Dike \& D’Amico, 2016). In addition, first generation students derived greater developmental benefits by taking mathematics, natural sciences, and engineering coursework than their continuing-generation peers (Pascarella et al., 2004). Collectively, these studies demonstrated the need for renewed attention to the STEM pathways of first-generation college students.

\section{Persistence and Completion in STEM}

Although the literature on first-generation college students in STEM has been limited, broader scholarship has illuminated factors important to the persistence and completion of STEM students. STEM majors have experienced disproportionate attrition within higher education (Ortiz \& Sriraman, 2015). NCES (2009) discovered a rate of STEM attrition of 36\% between 1995-6 and 2001. Moreover, only 37\% of those who entered a STEM field during their first year of college completed a degree or certificate over six years later. Additionally, STEM graduates were more likely to report English as a first language, to identify as a first-generation U.S. citizen or foreign citizen, and — particularly relevant to our study—have at least one parent with a bachelor's degree (Wolniak, 2016). 
Postsecondary students within STEM fields have been described by a number of characteristics. As a demographic, STEM students are younger than their peers in other disciplines and possessed higher ACT scores, cumulative credit hours, and grade point averages in high school and undergraduate coursework (Mau, 2016). STEM students who also identify as first-time college students, transfer students, and in remediation courses have decreased persistence (Mau, 2016). Confidence in STEM choice has been positively associated with views regarding professors, comparisons to peers, perceptions of the field as rewarding, and desirability of chosen major (Litzler, Samuelson, \& Lorah, 2014). Students within STEM fields (excepting computer/information sciences) differed from their peers in other fields by type of institutions attended, degree program, and attendance patterns (NCES, 2009).

Measures of STEM persistence typically begin in high school as students decide their interest related to math and science (Maltese \& Tai, 2011). Preparation in high school, such as coursework and performance, has been linked to higher STEM degree completion rates in college (NCES, 2009). Once on campus, GPA and enrollment in math and science gatekeeper courses during the first-semester relate positively to earning a STEM degree. (Crisp et al., 2009). Declaring a STEM major during a student's first year was a strong determinant of STEM degree completion across background characteristics (Wolniak, 2016). Moreover, students that chose their course of study through self-exploration rather than external factors reported higher values for individual competence, major selection, and personal effort (Perez et al., 2013). As so many of these early indicators can have a profound impact on STEM persistence, it is perhaps unsurprising that early, intentional conversations about STEM are important in shaping students' careers (Perez, Cromley, \& Kaplan, 2013; Wolniak, 2016). 
There has been no universal impact of social and academic integration on STEM completion (Wolniak, 2016; Xu, 2016). Influential factors on student retention included the academic quality provided by the institution, students' formal academic integration, and motivation for active learning. STEM students reported significantly higher dropout intention in instances where they felt less positive about the academic quality, experienced lower motivation, and enrolled in higher-level classes (Xu, 2016). Hernandez, Schultz, Estrada, Woodcock, and Chance (2012) found that goal setting influenced long term academic achievement and persistence in STEM even after controlling for background characteristics and prior achievement. Numerous researchers suggested key interventions to continue to support STEM success (Dagley, Georgiopoulos, Reece, \& Young; 2015; PCAST, 2012; Soldner, RowanKenyon, Inkelas, Garvey, \& Robbins, 2012). These programs outlined specific resources, academic support, and social interactions to support student persistence.

The barriers to STEM education have been particularly pronounced for marginalized student populations, especially women and under-represented minority (URM) students (defined as those who identify as African American, Latinx, or Native American). Asian/Pacific Islander students do not fall within the URM designation within STEM fields as they have been more likely than other racial groups to earn a degree in a science or engineering field (NSF, 2015b). Between 1995 and 2001, 47\% of Asian/Pacific Islander student entered STEM fields compared to $19-23 \%$ of students in other racial/ethnic groups (NCES, 2009). URM students persisted at a rate of $58.4 \%$ compared to $73.5 \%$ for Asian American students and $63.5 \%$ for White students (Chang et al., 2014). For Latinx/Hispanic students and African American students, six years after STEM enrollment $33 \%$ of Hispanic and $17 \%$ of African American students graduated compared to $46 \%$ of White students (Ortiz \& Sriraman, 2015). Women have also been disproportionately 
underrepresented in STEM fields (Ortiz \& Sriraman, 2015; Ro \& Loya, 2015; Wolniak, 2016), where race/ethnicity, perceptions of residence hall and campus racial climates, and academic self-confidence served as significant predictors of women's sense of belonging (Johnson, 2012). However, substantial scholarship has disagreed as to the influence of identity characteristics on STEM degree completion, with several studies not finding an impact (Maltese \& Tai, 2011;

Wilson et al., 2015). Therefore, this study on first-generation students in STEM furthers research on persistence across identity groups.

\section{Theoretical Framework and Research Questions}

As shown above, first-generation college students disproportionately come from economically and racially minoritized backgrounds. Prior research has also shown that students from economically or racially minoritized backgrounds experience disparate early educational experiences that contribute to restricted postsecondary outcomes - among them college-going and STEM participation. Based on these observations, we theorize that first-generation status may represent a convenient shorthand for a form of cumulative disadvantage (Crystal, 1986; Crystal \& Shea, 1990; DiPrete \& Eirch, 2006) and further, that this cumulative disadvantage may be uniquely felt by students on STEM pathways given the evidence of greater disparity in outcomes within these fields (NSF, 2015b). Cumulative disadvantage is a way of describing the increasing stratification of opportunities and outcomes across the life course: it holds that inequality can be explained by the interaction between demographics, variations in learning and development, and social systems (Crystal, Shea, \& Reyes, 2016). To ascertain the presence of cumulative disadvantage, researchers examine differences in the way that people have: 1) interacted with social systems, 2) been exposed to known risks and known opportunities; and 3) made individual decisions about risks to avoid and opportunities to pursue (Ferraro \& Shippe, 
2009). Consequently, our study seeks to understand the possible cumulative disadvantage experienced by first-generation college students within STEM by addressing the following research questions:

- To what extent does STEM degree completion differ for first-generation college students compared to continuing-generation college students?

- To what extent does STEM degree completion differ for first-generation college students compared to continuing-generation college students when adjusting for pre-college STEM experiences and demographic factors?

- To what extent are pre-college STEM experiences related to STEM degree completion differently for first-generation students compared to continuing-generation students?

\section{Data}

The United States National Center for Education Statistics' Education Longitudinal Study (ELS:2002/12) followed a nationally representative cohort of 2002 10th grade students throughout their high school and college years, with a fourth and final data collection wave in 2012, eight years after their expected high school graduation (Ingels et al., 2012). These data are nationally generalizable and are the most recent national data available to study college degree outcomes, which also include the pre-college background variables necessary for our study.

\section{Sample and Variables}

The analytic sample for our study included high school graduates who enrolled in postsecondary education within two years of their high school graduation. This explicitly included not only four-year college students, but also those who attended two-year institutions given that first-generation students are overrepresented at those institutions (Pascarella et al., 2004). By following those who may have delayed college entry for up to two years, we also 
captured more first-generation students, since first-generation students are more likely to delay college enrollment (Engle \& Tinto, 2008).

Dependent Variable. The dependent variable represented baccalaureate degree completion. This was a four-category dependent variable: a) dropout, b) no degree completion (but still enrolled in 2012), c) non-STEM degree completion, and d) STEM degree completion. For this study, STEM is defined based on the fields identified by the National Science and Mathematics Access to Retain Talent (SMART) Grant Program, which aligns well with the hardsoft paradigm distinction defined by Biglan (1973). By utilizing four categories for all college students, rather than strictly a STEM vs. non-STEM distinction with only degree completers in our sample, we obtained a nuanced look at differences in educational trajectories.

Independent Variables. Our main independent variable of interest was a dummy variable for first-generation status. We operationally defined a student as first-generation if no parent had obtained a bachelor's degree. In other words, if at least one parent had obtained a bachelor's degree, the student was considered a continuing-generation student. This definition produced a conservative model of the effect of first-generation status by including both students with and without firsthand knowledge of the postsecondary learning environments since some first-generation students will have parents that attended college but did not complete. Other independent variables were included as controls. We included a unique set of pre-college STEM factors as well as other demographic and educational experience controls.

The first group included pre-college STEM-specific characteristics and experiences not previously utilized in studies of the educational trajectories of first-generation college students. However, prior studies focused on other minoritized college-going populations revealed these characteristics to be significant indicators of STEM pathway outcomes (e.g., Crisp et al., 2009; 
Ro \& Loya, 2015; Wolniak, 2016). These variables were measures for parental STEM occupation, whether a student took an advanced level math course, whether a student took an advanced level science course, mathematics test scores, and mathematics self-efficacy.

The rest of the control variables were not specifically related to STEM pathways but prior studies have revealed them to be significant in predicting the educational trajectories of first-generation college students (e.g., Aspelmeier et al., 2012; Engle \& Tinto, 2008; Lohfink \& Paulsen, 2005; NCES, 2009; 2018; Pascarella et al., 2004). These included measures for educational expectations, familial income, reported biological sex, URM status, disability status, and high school GPA, as well as institutional selectivity, enrollment in a four-year college, persistence within the first institution attended, and enrollment in remedial coursework.

\section{Missing Data}

As with all secondary data analysis, missing data were an issue. We used multiple imputation to address missing data to retain the information from the full sample of collegegoing students, as it is the widely recommended choice to address missing data bias compared to listwise deletion (Manly \& Wells, 2015; van Buuren, 2012). The percentage of missing values on individual variables ranged from none for several demographic variables (using the standard single imputations provided by NCES) to almost $28 \%$ for math self-efficacy, with all but three variables having less than $15 \%$ missing data. Data were primarily missing due to item nonresponse. While participant attrition also existed, NCES refreshed the sample to keep the senior cohort data nationally representative. We included all analysis variables in our imputation model under the assumption that missing values are missing at random (Schafer \& Graham, 2002). Due to the complex design employed in the data collection, the primary sampling unit, strata, and weights were included in the imputation process (Heeringa, West, \& Berglund, 2010). 
Stata 14's 'mi impute chained' command generated 100 imputed datasets. Analyses run on each dataset were pooled according to Rubin's (1987) rules. Imputed values compared reasonably to observed values, and results using listwise deletion were similar to those we present using multiple imputation.

\section{Analyses}

Our analyses consisted of three main steps. First, we utilized descriptive statistics to understand our sample and to address our first research question. We examined mean values for all variables for first-generation and continuing-generation students separately, including the outcome of STEM degree completion, and tested whether these group mean differences were statistically significant. These descriptive analyses also helped to make meaning of results in our next steps, by understanding the ways that first- and continuing-generation students differ.

Second, we investigated the relationship between first-generation status and degree outcomes using multinomial logistic regression. This was the appropriate technique for a multicategorical dependent variable (Long, 1997). By using STEM degree completion as the reference category in the dependent variable, we effectively examined dropout, non-completion (but still enrolled), as well as non-STEM degree completion, all relative to completing a STEM degree. This analysis allowed us to address the second research question, in order to better understand how generation status was related to STEM degree completion when adjusted for additional factors.

Given that we are interested in differences between first-generation and continuationgeneration students, we did not want to artificially assume that the variables in our model would have the same relationship to the outcome for each group. Therefore, and consistent with recommendations from Long \& Mustillo (forthcoming), we analyzed a regression model that 
was fully interacted with respect to generational status, and therefore allows relationships of variables to outcomes to be heterogenous across groups. While we present odds ratios for these analysis in an appendix, we report and focus on marginal effects as these are more intuitive and interpretable given our nonlinear dependent variable. As the ELS data collection followed a complex sampling strategy, all analyses accounted for this design using Stata's svy command (Heeringa et al., 2010). This technique also properly weighted the analyses per NCES standards to account for oversampling and some nonresponse.

Third, to directly address our final research question, we compared first-generation and continuing-generation students to understand if the variables in our models had similar or different relationships with the dependent variable for these groups. For this purpose, we used regression results to calculate the average discrete change (ADC) for pre-college STEM variables across groups, and statistically compared the resulting changes in probability (Long \& Mustillo, forthcoming). For further insight, we calculated the probability of each group with a set of high-STEM pre-college predictors (parents both had a STEM occupation, student took the highest math and science courses available, scored at the 80 th percentile on a math test, and had math self-efficacy at the 80th percentile) and a set of low-STEM pre-college factors (neither parent had a STEM occupation, took math and science but at a low level, and scored at the 20 th percentile on both math test and math self-efficacy), or what Long \& Freese (2014) refer to as "ideal types" analyses.

\section{Descriptive Results}

Table 1 shows the means of all variables separated into all, first-generation, and continuing-generation student groups. All variables in this table had statistically significant differences between first- and continuing-generation students, except for disability status. First- 
generation students in this sample were less likely than continuing-generation students to complete college with a STEM degree (9\% versus $15 \%$ respectively). Additionally, they were less likely to complete a non-STEM degree (57\% versus $65 \%)$. In other words, not only were first-generation students less likely to attain a STEM degree, they were simply less likely to attain any degree. This is further confirmed by results showing that first-generation students were more likely to drop out (25\% versus $13 \%$ ) and also more likely to remain enrolled but not to have attained a degree by 2012 (9\% versus 6\%).

<insert Table 1 about here >

Also apparent from these descriptive statistics is that first-generation students were constrained in their pre-college STEM exposure and experiences. Compared to continuinggeneration students, they did not take part in math and science courses at high levels to the same degree, attained lower math test scores, exhibited lower levels of math self-efficacy, and were less likely to have parents in STEM careers. Comparisons across the remainder of the variables also show first-generation students' experiences to have been quite different than those for continuing-generation students. For example, first-generation students had lower educational expectations when in high school, which matched their lower average GPAs. They also had lower family incomes, and were more likely to identify as an URM than their peers. Firstgeneration students attended less selective institutions and were less likely to attend four-year colleges (relative to less than four-year). Next, we investigated how these factors help to explain the gap in STEM degree completion via multinomial logistic regression.

\section{Regression Results}

Multinomial logistic regression results allow one to gain a better understanding of the key predictors of STEM degree completion, relative to non-STEM degree completion, dropout, and 
no degree. Table 2 shows these results as average marginal affects (AMEs), which can be interpreted as a change in the probability of a particular outcome, given a very small change in the independent variables (or a one-unit change in dichotomous variables) 1.

<insert Table 2 about here >

In Table 2, generation status was not predictive of attaining a STEM degree. However, first generation students still had a probability of attaining a non-STEM degree that was about 4 percentage points lower than continuing-generation students. In contrast, first-generation students were about 4 percentage points more likely than other students to drop out. In looking at what was predictive of STEM degree completion, the pre-college STEM factors were consistently significant. In addition to common variables like advanced math and science coursetaking and math test scores, STEM variables related to self-efficacy and parental occupation also predicted higher probabilities of STEM degree attainment (though only marginally for parental occupation, given our large sample size). Gender and pre-college academics were predictive of STEM degrees in ways consistent with the literature broadly—women had lower probabilities of STEM degrees but higher probability of a non-STEM degree, whereas high school GPA was a positive predictor of both outcomes. Additionally, if a student persisted at their original postsecondary institution, they had about a 7 percentage point advantage in the probability of STEM degree completion as compared to those who transferred.

To understand if pre-STEM factors were more predictive of STEM degree completion for either first- or continuing-generation students, we utilized a comparison of the average discrete

1 Results from the logistic regression presented as odds ratios are found in Appendix B, with independent variables blocked in hierarchically to show, for example, how a model with only pre-college STEM factors behaves. While a common way to present regression, interpreting results by comparing results from different variable blocks is not appropriate given the non-linear nature of the dependent variable (Breen, Karlson \& Holm, 2018), and we therefore focus our attention on AMEs for the full model in Table 2. 
change (ADC). A discrete change is a measure of the change in probability of an outcome, given a specified change in the independent variable. We evaluated a change of plus one for dichotomous independent variables of interest related to STEM background. For the continuous variables, we chose a change of one standard deviation to give a sense of the change in a meaningful metric for standardized variables. The ADC is the average of these discrete changes computed conditionally from the regression results for each student, using that student's values for the other variables in the model (Long \& Mustillo, forthcoming). We calculate the ADC for each of the pre-college STEM variables for both the first-generation and continuing generation students, and statistically compared these changes.

<insert Table 3 about here >

As shown in Table 3, pre-college STEM factors had nearly identical effects for both groups. This was true for the outcome of STEM degree completion (Panel A) and also for nonSTEM degree completion (Panel B). So, while first-generation and continuing-generation students are quite different in their pre-college STEM exposure and experiences (see Table 1), heterogeneous relationships of these experiences with STEM degree attainment were minimal. The possible exception to this is for math test score, which may have a slightly more positive relationship to degree outcomes for continuing-generation students.2

Comparing first- and continuing-generation students with specific high-STEM and lowSTEM pre-college experience profiles confirmed that the probability of degree outcomes was not

2 There are many possible ways to compare groups using marginal effects (see Long \& Mustillo, forthcoming). To test the robustness of our results, we also calculated and compared values for discrete change at the mean (DCM). For both ADC and DCM calculations, we conducted the analyses using a) mean values of the variables from the overall combined sample (i.e., the grand mean) as well as b) mean values of the variables within each group (i.e., local or group mean). Results available upon request. In all cases, the substantive findings were the same: there are few differences in the association between pre-college STEM factors and degree outcome, with the possible exception that math test score is more strongly related for continuing-generation students. 
statistically significantly different between groups.3 As with all regression-based results, these comparisons assumed all else to be equal on covariates in the model. However, these variables, and pre-college STEM factors specifically, are not similar across groups, with first-generation students at a consistent disadvantage.

\section{Discussion and Implications}

Prior studies have shown both that the educational trajectories of first-generation college students differ appreciably from their continuing-generation peers (Engle et al., 2006; Engle \& Tinto, 2008) and that success within STEM careers begins in early educational experiences (Maltese \& Tai, 2011; Mau, 2016; NCES, 2009). Our findings highlight the extent to which divergences in STEM completion outcomes arise from inequitable access to economic and educational opportunities. While first-generation status is a significant predictor of STEM completion in a simple group-mean comparison, when adjusted for numerous factors, including pre-college STEM variables, there is not a difference. In other words, STEM experiences and socialization prior to college are predictive of postsecondary STEM outcomes, and are likely part of the explanation for lower rates of STEM completion for first-generation students. These early experiences shape subsequent choices and opportunities, creating a trajectory of cumulative disadvantage (DiPrete \& Eirich, 2006; Ferraro \& Shipper, 2009) for first-generation students pursuing STEM degrees.

Our study found that first-generation college students were less likely to take the sort of rigorous math and science courses in high school that allow for a smoother transition into STEM majors. They also scored lower on relevant tests, had lower GPAs, and displayed lower math self-efficacy. Given prior research that suggests the importance of early successes in college

3 Results not included, but available on request. 
STEM course work (e.g., Crisp et al., 2009; Wolniak, 2016) as well as a durable, positive selfconcept (e.g., Hernandez et al., 2012; Perez et al., 2013), these findings are particularly concerning. While more work on this topic is warranted, our findings offer one notable starting point: the observation that pre-college science and mathematics experiences are predictive of STEM degree completion on average, and yet these experiences are vastly different for first- and continuing-generation college students.

Given the stratification of access to high quality schooling in the United States, this problem is likely exacerbated by the demographic realities of first-generation college students. Results in Table 1 confirm that first-generation students are disproportionately likely be from low income families and to report a race or ethnicity presently underrepresented in most postsecondary institutions (Pascarella et al., 2004). First-generation college students may find themselves sorted into different educational opportunities early in their academic careers based on such factors. As a mechanism of cumulative advantage, these inequities are likely to be magnified over time.

There is reason to suggest that the inequities of STEM completion are exaggerated by the intergenerational impact of STEM experience. Indeed, students with a parent with a STEM occupation have been more likely to choose STEM majors than peers whose parents had differential occupations (Moakler \& Kim, 2014). Intergenerational STEM aspirations may derive from parental dispositions, as prior research has found that parental behavior and practices can have a role on their children's STEM aspirations (Niu, 2016) and persistence within STEM careers (Ing, 2014). It may be that cumulative disadvantage in this sense means that parental exposure to STEM concepts and careers, tied to their own education level, is then passed along to children. This aligns with our findings suggesting that parental STEM occupations are 
predictive of STEM degree completion (though more research is needed to confirm this result) combined with the result that first-generation students are less likely to have such a parent.

Therefore, our findings confirm other research that suggests that college outcomes typically attributed to first-generation status or familial support may actually be predicted by other factors (Dennis, Phinney, Chuateco, 2005; Nguyen \& Nguyen, 2018). Further research can continue to disaggregate first-generation student populations to provide more in-depth analysis across gender, race/ethnicity, disability, and other intersectional marginalized identities. Educational trajectories also often have high degrees of nuance, as first-generation students are more likely to attend two-year institutions. Given that transfer status is negatively associated with STEM persistence (Mau, 2016), supported by our finding that persisting at one's first institution (i.e., no transfer) is positively related to degree completion, these educational trajectories may provide an example of how cumulative disadvantage can affect first-generation student experiences. Thus, conducting analyses that examine community colleges and transfer experiences is an additional important contribution needed to illuminate the STEM degree pathway.

Attempts to decrease the gap should focus on much earlier interventions. These interventions have been proven to be important in STEM conversations broadly (Perez, Cromley, \& Kaplan, 2013; Wolniak, 2016), but may necessitate a more targeted approach for firstgeneration students. These efforts may also be enhanced by out-of-school activities associated with career interest in STEM (Dabney et al., 2011). While multiple federally funded TRIO programs focus on these pre-college experiences geared towards student experience (e.g., Upward Bound, Educational Talent Search), a practical implication of this study is to focus more specifically on STEM trajectories for first-generation populations. Future research such as meta- 
analysis that examines the factors that lead to STEM completion for marginalized populations would be beneficial to understand the trends of completion over time, and further shape firstgeneration student interventions within this context.

Taken as a whole, our work demonstrates how limited pre-college STEM-specific experiences and generally poor postsecondary outcomes contribute to limited STEM completion for first-generation college students. The inequitable STEM pipeline these students face starting in high school thereby presents a significant equity concern for economic disparity later in life. Simply put, systemic intervention is warranted given that first-generation college students do not have the same likelihood of earning a degree in STEM as do continuing-generation college students (i.e., only $9 \%$ of first-generation students did in our study compared to $15 \%$ ). Our findings suggest the importance of the cultivation of positive STEM experiences in secondary education, a malleable factor within the control of educational systems. While these experiences may not be within the control of higher education institutions, they can be taken into account in the design of STEM curricula and relevant student services. This shift can be described as moving away from placing the onus on students to be college-ready to instead encourage institutions to be student-ready by providing intentional, inclusive ways to support the success of diverse groups (McNair, Albertine, Cooper, McDonald, \& Major, 2016). In addition to specific opportunities, these strategies include shaping institutions that reflect the characteristics of the students they serve by offering diverse role models, challenging deficit labels, and providing more holistic and integrated support structures (McNair et al., 2016). Overall, our findings provide important evidence that can contribute toward the development of equitable STEM experiences for first-generation college students. 


\section{References}

Aspelmeier, J. E., Love, M. M., McGill, L. A., Elliott, A. N., \& Pierce, T. W. (2012). Selfesteem, locus of control, college adjustment, and GPA among first- and continuinggeneration students: A moderator model of generational status. Research in Higher Education, 53(7), 755-781. doi:10.1007/s1162-011-9252-1

Biglan, A. (1973). The characteristics of subject matter in different areas. Journal of Applied Psychology, 57(3), 195-203.

Breen, R., Karlson, K. B., \& Holm, A. (2018). Interpreting and understanding logits, probits, and other nonlinear probability models. Annual Review of Sociology, 44(1), 39-54. https://doi.org/10.1146/annurev-soc-073117-041429

Bush, V. (1945). Science, the endless frontier. Washington, DC: United States Government Printing Office.

Cataldi, E. F., Bennett, C. T., \& Chen, X. (2018). First-generation students: College access, persisitence, and postbachelor's outcomes (NCES 2018-421). U.S. Department of Education. Washington, DC: National Center for Education Statistics. Retrieved from https://nces.ed.gov/pubs2018/2018421.pdf

Chang, M. J., Sharkness, J., Hurtado, S., \& Newman, C. B. (2014). What matters in college for retaining aspiring scientists and engineers from underrepresented racial groups. Journal of Research in Science Teaching, 51(5), 555-580. doi:10.1002/tea/21145

Clogg, C. C., Petkova, E., \& Haritou, A. (1995). Statistical methods for comparing regression coefficients between models. American Journal of Sociology, 100(5), 1261-93.

Crisp, G., Nora, A., \& Taggart, A. (2009). Student characteristics, pre-college, college, and environmental factors as predictors of majoring in and earning a STEM degree: An 
analysis of students attending a Hispanic serving institution. American Educational Research Journal, 46(4), 924-942. doi:10.3102/0002831209349460

Crystal, S. (1986). Measuring income and inequality among the elderly. The Gerontologist, 26(1), 56-59.

Crystal, S., \& Shea, D. (1990). Cumulative advantage, cumulative disadvantage, and inequality among elderly people. The Gerontologist, 30(4), 437-443.

Crystal, S., Shea, D. G., \& Reyes, A. M. (2016). Cumulative advantage, cumulative disadvantage, and evolving patterns of late-life inequality. The Gerontologist, 57(5), 910920.

Dabney, K. P., Tai, R. H., Almarode, J. T., Miller-Friedmann, J. L., Sonnert, G., Sadley, P. M., \& Hazari, Z. (2011). Out-of-school time science activities and their association with career interest in STEM. International Journal of Science Education, 2(1), 63-79. doi: $10.1080 / 21548455.2011 .629455$

Dagley, M., Georgiopoulos, M., Reece, A., \& Young, C. (2016). Increasing retention and graduation rates through a STEM learning community. Journal of College Student Retention: Research, Theory \& Practice, 18(2), 167-182.

doi:10.1177/1521025115584746

Dennis, J. M., Phinney, J.S., \& Chuateco, L. I. (2005). The role of motivation, parental support, and peer support in the academic success of ethnic minority first-generation college students. Journal of College Student Development, 46(3), 223-236. doi:

$10.1353 / \mathrm{csd} .2005 .0023$ 
Dika, S. L. \& D’Amico, M. M. (2015). Early experiences and integration in the persistence of first-generation college students in STEM and non-STEM majors. Journal of Research in Science Teaching, 53(3), 368-383. doi:10.1002/tea.21301

DiPrete, T. A., \& Eirich, G. M. (2006). Cumulative advantage as a mechanism for inequality: A review of theoretical and empirical developments. Annual Review of Sociology, 32, 271297.

Engle, J., Bermeo, A., \& O'Brien, C. (2006). Straight from the source: What works for firstgeneration college students. Washington, DC: Pell Institute for the Study of Opportunity in Higher Education.

Engle, J., \& Tinto, V. (2008). Moving beyond access: College success for low-income, firstgeneration students. Washington, DC: The Pell Institute for the Study of Opportunity in Higher Education.

Ferraro, K. F., \& Shippee, T. P. (2009). Aging and cumulative inequality: How does inequality get under the skin?. The Gerontologist, 49(3), 333-343.

Gayles, J. G. \& Ampaw, F. (2014). The impact of college experiences on degree completion in STEM fields at four-year institutions: Does gender matter? The Journal of Higher Education, 85(4), 439-468. doi:10.1353/jhe.2014.0022

Heeringa, S., West, B. T., \& Berglund, P. A. (2010). Applied survey data analysis. Boca Raton, FL: Chapman \& Hall.

Hernandez, P. R., Schultz, P. W., Estrada, M., Woodcock, A., \& Chance, R. D. (2013). Sustaining optimal motivation: A longitudinal analysis of interventions to broaden participation of underrepresented students in STEM. Journal of Educational Psychology, 105(1), 89-107. doi:10.1037/a0029691 
Ing, M. (2014). Can parents influence children's mathematics achievement and persistence in STEM careers? Journal of Career Development, 41(2), 87-103. doi: $10.1177 / 0894845313481672$

Ingels, S. J., Pratt, D. J., Jewell, D. M., Mattox, T., Dalton, B., Rosen, J., Lauff, E., and Hill, J. (2012). Education Longitudinal Study of 2002 (ELS:2002/12) third follow-up field test report (NCES 2012-03). Washington, DC: U.S. Department of Education, Institute of Education Sciences, National Center for Education Statistics.

Ishitani, T. T. (2006). Studying attrition and degree completion behavior among first-generation college students in the United States. The Journal of Higher Education, 77(5), 861-885. doi:10.1353/jhe.2006.0042

Jehangir, R. (2010). Stories as knowledge: Bringing the lived experience of first-generation college students into the academy. Urban Education, 45(4), 533-553.

Johnson, D.R. (2012). Campus racial climate perceptions and overall sense of belonging among racially diverse women in STEM majors. Journal of College Student Development, 53(2)-336-346. doi:10.1353/csd.2012.0028

Kim, Y. K. \& Sax, L. J. (2009). Student-faculty interaction in research universities: Differences by student gender, race, social class, and first-generation status. Research in Higher Education, 50(5), 437-459. doi:10.1007/s11162-009-9127-x

Litzler, E., Samuelson, C. C., \& Lorah, J. A. (2014). Breaking it down: Engineering student STEM confidence at the intersection of race/ethnicity and gender. Research in Higher Education, 55, 810-832. doi:10.1007/s11162-014-9333-z 
Lohfink, M. M. \& Paulsen, M. B. (2005). Comparing the determinants of persistence for firstgeneration and continuing-generation students. Journal of College Student Development, 46(4), 409-428. doi:10.1353/csd.2005.0040

Long, J. S. (1997). Regression models for categorical and limited dependent variables. Thousand Oaks, CA: SAGE.

Long, J. S., \& Freese, J. (2014). Regression models for categorical dependent variables using Stata, $3 r d$ ed. College Station, TX: Stata Press.

Long, J. S., \& Mustillo, S. A. (forthcoming). Using predictions and marginal effects to compare groups in regression models for binary outcomes. Sociological Methods and Research.

Maltese, A. V. \& Tai, R. H. (2011). Pipeline persistence: Examining the association of educational experiences with earned degrees in STEM among U.S. students. Science Education Policy, 95(5), 877-907. doi:10.1002/sce.20441

Manly, C. A., \& Wells, R. S. (2015). Reporting the use of multiple imputation for missing data in higher education research. Research in Higher Education, 56(4), 397-409. doi:10.1007/s11162-014-9344-9

Mau, W. J. (2016). Characteristics of US students that pursued a STEM major and factors that predicted their persistence in degree completion. Universal Journal of Educational Research, 4(6), 1495-1500. doi:10.13189/ujer.2016.040630

McCarron, G. P. \& Inkelas, K. K. (2006). The gap between educational aspirations and attainment for first-generation college students and the role of parental involvement. Journal of College Student Development, 47(5), 534-549. doi:10.1353/csd.2006.0059 
McNair, T. B., Albertine, S., Cooper, M. A., McDonald, N., \& Major, T., Jr. (2016). Becoming $a$ student-ready college: A new culture of leadership for student success. San Francisco, CA: Jossey-Bass.

Melguizo, T. \& Wolniak, G. C. (2012). The earnings benefits of majoring in STEM fields among high achieving minority students. Research in Higher Education, 53, 383-405, doi:10.1007/s11162-011-9238-z

Moakler, M.W., Jr., \& Kim, M. M. (2014). College major choice in STEM: Revisiting confidence and demographic factors. The Career Development Quarterly, 62(2), 128142. doi: 10.1002/j.2161-0045.2014.00075.x

National Center for Education Statistics. (2018). First-generation students: College access, persistence, and postbachelor's outcomes. Retrieved from https://nces.ed.gov/pubs2018/2018421.pdf

National Center for Education Statistics. (2009). Students who study science, technology, engineering, and mathematics (STEM) in postsecondary education. Retrieved from https://nces.ed.gov/pubs2009/2009161.pdf

National Science Foundation (NSF), National Science Board (2015a). Revisiting the STEM workforce. NSB-2015-10. Retrieved from: http://www.nsf.gov/nsb/publications/ 2015/nsb201510.pdf

National Science Foundation (NSF), National Center for Science and Engineering Statistics. (2015b). Women, minorities, and persons with disabilities in science and engineering: 2015. Special report NSF 15-311. Arlington, VA: Author. Retrieved from: http://www.nsf.gov/statistics/2015/nsf15311/digest/theme3.cfm 
Nguyen, T., \& Nguyen, B. M. d. (2018). Chapter 7: Is the "first-generation student" term useful for understanding inequality? The role of intersectionality is illuminating the implications of an accepted-yet unchallenged-term. Review of Research in Education, 42, , 146-176. doi: 10.3102/0091732X18759280

Niu, L. (2016). Parental motivational practice, parent involvement, and students' choice of study field in college. World Journal of Education, 6(5), 36-48. doi: 10.5430/wje.v6n5p36

Ortiz, A. M. \& Sriraman, V. (2015). Exploring faculty insights into why undergraduate students leave STEM fields of study-A three-part organizational self-study. American Journal of Engineering Education, 6910, 43-60.

Padgett, R. D., Johnson, M. P., \& Pascarella, E. T. (2012). First-generation undergraduate students and the impacts of the first year of college: Additional evidence. Journal of College Student Development, 53(2), 243-266. doi:10.1353/csd.2012.0032

Pascarella, E. T., Pierson, C. T., Wolniak, G. C., \& Terenzini, P. T. (2004). First-generation college students: Additional evidence on college experiences and outcomes. The Journal of Higher Education, 75(3), 249-284. doi:10.1353/jhe.2004.0016

Perez, T., Cromley, J. G., \& Kaplan, A. (2014). The role of identity development, values, and costs in college STEM retention. Journal of Educational Psychology, 106(1), 315-329. doi:10.1037/a0034027

Pike, G. R. \& Kuh, G. D. (2005). First- and second-generation college students: A comparison of their engagement and intellectual development. Journal of Higher Education, 76(3), 276300. doi:10.1353/jhe. 2005.0021

President's Council on Advisors on Science and Technology (2012). Engage to EXCEL: Producing one million additional college graduates with degrees in science, technology, 
engineering, and mathematics. Retrieved from

https://obamawhitehouse.archives.gov/sites/default/files/microsites/ostp/pcast-engage-toexcel-final_2-25-12.pdf

Ro, H. K. \& Loya, K. I. (2015). The effect of gender and race intersectionality on student learning outcomes in engineering. Review of Higher Education, 38(3), 359-396. doi:10.1353/rhe.2015.0014

Rubin, D. B. (1987). Multiple imputation for nonresponse in surveys. New York, NY: Wiley.

Schafer, J. L., \& Graham, J. W. (2002). Missing data: Our view of the state of the art. Psychological Methods, 7(2), 147-177. doi:10.1037/1082-989X.7.2.147.

Skomsvold, P. (2015). Web tables—Profile of Undergraduate Students: 2011-12 (NCES 2015167). U.S. Department of Education. Washington, DC: National Center for Education Statistics. Retrieved from https://nces.ed.gov/pubsearch/ pubsinfo.asp?pubid=2015167.

Soldner, M., Rowan-Kenyon, H., Inkelas, K. K., Garvey, J., \& Robbins, C. (2012). Supporting students' intentions to persist in STEM disciplines: The role of living-learning programs among other social-cognitive factors. The Journal of Higher Education, 83(3), 311-336. doi:10.1353/jhe.2012.0017

Terenzini, P. T., Springer, L., Yaeger, P. M., Pascarella, E. T., \& Nora, A. (1996). Firstgeneration college students: Characteristics, experiences, and cognitive development. Research in Higher Education, 37(1), 1-22.

Wilson, D., Jones, D., Bocell, F., Crawford, J., Kim, M. J., Veilleux, N., Floyd-Smith, T., Bates, R., \& Plett, M. (2015). Belonging and academic engagement among undergraduate STEM students: A multi-institutional study. Research in Higher Education, 56, 750-776. doi:10.1007/s11162-015-9367-x 
Wolniak, G. C. (2016). Examining STEM bachelor's degree completion for students with differing propensities at college entry. Journal of College Student Retention: Research, Theory \& Practice, 18(3), 287-309. doi:10.1177/1521025115622782

van Buuren, S. (2012). Flexible imputation of missing data. Boca Raton, FL: CRC Press.

Wang, X. (2013). Why students choose STEM majors: Motivation, high school learning, and postsecondary context of support. American Educational Research Journal, 50(5). doi: $10.3102 / 0002831213488622$

Xu, Y. J. (2013). Career outcomes of STEM and non-STEM college graduates: Persistence in majored-field and influential factors in career choices. Research in Higher Education, 54(3), 349-382. doi:10.1007/s11162-012-9275-2

$\mathrm{Xu}$, Y. J. (2016). Attention to retention: Exploring and addressing the needs of college students in STEM majors. Journal of Education and Training Studies, 4(2), 67-76.

doi:10.11114/jets.v4i2.1147 
Table 1.

Estimated (weighted) means and standard deviations for college attendees, including the difference between first generation and continuing generation students

\begin{tabular}{|c|c|c|c|c|c|c|c|}
\hline \multirow[b]{2}{*}{ Variables } & \multicolumn{2}{|c|}{ All } & \multicolumn{2}{|c|}{ First Generation } & \multicolumn{2}{|c|}{$\begin{array}{l}\text { Continuing } \\
\text { Generation }\end{array}$} & \multirow{2}{*}{$\begin{array}{c}\text { Difference } \\
\text { FG - CG }\end{array}$} \\
\hline & Mean & SD & Mean & $\mathrm{SD}$ & Mean & SD & \\
\hline \multicolumn{8}{|l|}{ College degree attained } \\
\hline Drop out & 0.19 & 0.39 & 0.25 & 0.43 & 0.13 & 0.34 & $0.11 * *$ \\
\hline No degree attained & 0.08 & 0.27 & 0.09 & 0.29 & 0.06 & 0.24 & $0.03 * *$ \\
\hline Non-STEM degree attained & 0.61 & 0.49 & 0.57 & 0.49 & 0.65 & 0.48 & $-0.08 * *$ \\
\hline STEM degree attained & 0.12 & 0.33 & 0.09 & 0.29 & 0.15 & 0.36 & $-0.06 * *$ \\
\hline First generation status & 0.53 & 0.50 & 1.00 & & 0.00 & & \\
\hline Mom STEM occupation & 0.15 & 0.35 & 0.09 & 0.29 & 0.21 & 0.41 & $-0.12 * *$ \\
\hline Dad STEM occupation & 0.13 & 0.34 & 0.06 & 0.24 & 0.22 & 0.41 & $-0.15 * *$ \\
\hline High level of HS math & 0.39 & 0.49 & 0.29 & 0.46 & 0.49 & 0.50 & $-0.20 * *$ \\
\hline High level of HS science & 0.41 & 0.49 & 0.32 & 0.47 & 0.51 & 0.50 & $-0.18 * *$ \\
\hline Math test score & 0.24 & 0.93 & 0.01 & 0.89 & 0.50 & 0.92 & $-0.49 * *$ \\
\hline Math self-efficacy & 0.04 & 1.01 & -0.05 & 0.98 & 0.14 & 1.03 & $-0.19 * *$ \\
\hline Selective college & 0.48 & 0.50 & 0.36 & 0.48 & 0.63 & 0.48 & $-0.27 * *$ \\
\hline Four-year institution & 0.60 & 0.49 & 0.49 & 0.50 & 0.73 & 0.44 & $-0.24 * *$ \\
\hline Persisted at 1 st institution & 0.44 & 0.50 & 0.40 & 0.49 & 0.50 & 0.50 & $-0.10 * *$ \\
\hline Remedial course & 0.43 & 0.49 & 0.50 & 0.50 & 0.34 & 0.47 & $0.17 * *$ \\
\hline Student expects $>=\mathrm{BA}$ & 0.80 & 0.40 & 0.74 & 0.44 & 0.87 & 0.33 & $-0.14 * *$ \\
\hline Family income (\$10k) & 7.21 & 5.98 & 5.11 & 3.87 & 9.64 & 6.98 & $-4.53 * *$ \\
\hline Female & 0.54 & 0.50 & 0.56 & 0.50 & 0.52 & 0.50 & $0.04 *$ \\
\hline White/Asian & 0.71 & 0.45 & 0.65 & 0.48 & 0.78 & 0.42 & $-0.13 * *$ \\
\hline URM & 0.29 & 0.45 & 0.35 & 0.48 & 0.22 & 0.42 & $0.13 * *$ \\
\hline Disability status & 0.09 & 0.29 & 0.10 & 0.29 & 0.09 & 0.28 & 0.01 \\
\hline HS GPA & 2.97 & 0.65 & 2.86 & 0.65 & 3.11 & 0.62 & $-0.25 * *$ \\
\hline Observations & 9,270 & & 4,520 & & 4,760 & & \\
\hline
\end{tabular}

Source: Education Longitudinal Study (ELS 2002/2012)

Note: NCES math test score and math self-efficacy score are standardized. All reported sample sizes are rounded to the nearest 10 in accordance with NCES restricted data license. For difference between first generation and continuing generation groups, $* * \mathrm{p}<0.001 ; * \mathrm{p}<0.01 ;+\mathrm{p}<0.05$ 
Table 2. Average marginal effects of 10th graders having achieved STEM college completion, non-STEM college completion, no college degree, and dropping out within 10 years

\begin{tabular}{|c|c|c|c|c|}
\hline Variables & Dropout & No Degree & $\begin{array}{c}\text { Non- } \\
\text { STEM } \\
\text { Degree }\end{array}$ & $\begin{array}{l}\text { STEM } \\
\text { Degree }\end{array}$ \\
\hline \multirow[t]{2}{*}{ First generation status } & $0.043 * *$ & -0.005 & $-0.038 *$ & -0.000 \\
\hline & $(0.010)$ & $(0.008)$ & $(0.014)$ & $(0.010)$ \\
\hline \multirow[t]{2}{*}{ Mom STEM occupation } & -0.012 & -0.001 & -0.022 & $0.034+$ \\
\hline & $(0.014)$ & $(0.012)$ & $(0.019)$ & $(0.014)$ \\
\hline \multirow[t]{2}{*}{ Dad STEM occupation } & -0.011 & 0.012 & -0.039 & $0.037+$ \\
\hline & $(0.017)$ & $(0.014)$ & $(0.022)$ & $(0.015)$ \\
\hline \multirow[t]{2}{*}{ High level of HS math } & $-0.037 *$ & -0.006 & 0.001 & $0.043 * *$ \\
\hline & $(0.012)$ & $(0.010)$ & $(0.016)$ & $(0.011)$ \\
\hline \multirow[t]{2}{*}{ High level of HS science } & -0.011 & -0.016 & -0.011 & $0.038 * *$ \\
\hline & $(0.011)$ & $(0.008)$ & $(0.015)$ & $(0.010)$ \\
\hline \multirow[t]{2}{*}{ Math test score } & 0.004 & 0.007 & $-0.044 * *$ & $0.033 * *$ \\
\hline & $(0.007)$ & $(0.006)$ & $(0.010)$ & $(0.008)$ \\
\hline \multirow[t]{2}{*}{ Math self-efficacy } & 0.001 & $0.010+$ & $-0.026 * *$ & $0.016 *$ \\
\hline & $(0.005)$ & $(0.005)$ & $(0.008)$ & $(0.005)$ \\
\hline \multirow[t]{2}{*}{ Selective college } & -0.010 & $-0.029 *$ & 0.034 & 0.005 \\
\hline & $(0.016)$ & $(0.011)$ & $(0.023)$ & $(0.017)$ \\
\hline \multirow[t]{2}{*}{ Four-year institution } & -0.001 & 0.016 & -0.000 & -0.016 \\
\hline & $(0.014)$ & $(0.011)$ & $(0.024)$ & $(0.019)$ \\
\hline \multirow[t]{2}{*}{ Persisted at 1 st institution } & $-0.304 * *$ & $-0.020+$ & $0.260 * *$ & $0.065 * *$ \\
\hline & $(0.008)$ & $(0.008)$ & $(0.012)$ & $(0.009)$ \\
\hline \multirow[t]{2}{*}{ Remedial course } & 0.008 & $0.036^{* *}$ & $-0.034+$ & -0.011 \\
\hline & $(0.010)$ & $(0.008)$ & $(0.015)$ & $(0.011)$ \\
\hline \multirow[t]{2}{*}{ Student expects $>=\mathrm{BA}$} & $-0.054 * *$ & 0.008 & $0.065 *$ & -0.019 \\
\hline & $(0.012)$ & $(0.010)$ & $(0.021)$ & $(0.018)$ \\
\hline \multirow[t]{2}{*}{ Family income (\$10k) } & -0.002 & $-0.003 *$ & $0.006 * *$ & -0.001 \\
\hline & $(0.001)$ & $(0.001)$ & $(0.001)$ & $(0.001)$ \\
\hline \multirow[t]{2}{*}{ Female } & $-0.036 * *$ & -0.006 & $0.124 * *$ & $-0.082 * *$ \\
\hline & $(0.009)$ & $(0.008)$ & $(0.013)$ & $(0.010)$ \\
\hline \multirow[t]{2}{*}{ URM } & -0.005 & 0.011 & -0.030 & 0.024 \\
\hline & $(0.010)$ & $(0.009)$ & $(0.016)$ & $(0.013)$ \\
\hline \multirow[t]{2}{*}{ Disability status } & 0.030 & 0.004 & -0.027 & -0.007 \\
\hline & $(0.016)$ & $(0.013)$ & $(0.025)$ & $(0.022)$ \\
\hline \multirow[t]{2}{*}{ HS GPA } & $-0.067 * *$ & $-0.044 * *$ & $0.068 * *$ & $0.043 * *$ \\
\hline & $(0.010)$ & $(0.007)$ & $(0.015)$ & $(0.011)$ \\
\hline
\end{tabular}




\begin{tabular}{lllll}
\hline Observations & 9,270 & 9,270 & 9,270 & 9,270
\end{tabular}

Source: Education Longitudinal Study (ELS 2002/2012)

Note: Standard errors in parentheses. All reported sample sizes are rounded to the nearest 10 in accordance with NCES restricted data license. ${ }^{* *} \mathrm{p}<0.001 ; * \mathrm{p}<0.01 ;+\mathrm{p}<0.05$ 
Table 3. Average discrete change (ADC) - for changes of +1 for dichotomous variables (e.g., STEM occupation, high level of HS math) and +SD for continuous variables (e.g., math test score)

\begin{tabular}{lccccc}
\hline & $\begin{array}{c}\text { First } \\
\text { Generation } \\
\text { Probability }\end{array}$ & $\begin{array}{c}\text { Continuing } \\
\text { Generation } \\
\text { Probability }\end{array}$ & $\begin{array}{c}\text { First } \\
\text { Generation } \\
\text { ADC }\end{array}$ & $\begin{array}{c}\text { Continuing } \\
\text { Generation } \\
\text { ADC }\end{array}$ & $\begin{array}{c}\text { Difference } \\
\text { FG - CG }\end{array}$ \\
\hline Panel A: STEM Degree Outcomes & & & & & \\
Mom STEM occupation & 0.15 & 0.145 & 0.037 & $0.031+$ & 0.006 \\
Dad STEM occupation & 0.141 & 0.159 & 0.026 & $0.047^{*}$ & -0.021 \\
High level of HS math & 0.148 & 0.131 & $0.059^{*}$ & 0.027 & 0.032 \\
High level of HS science & 0.137 & 0.136 & $0.038+$ & $0.038^{*}$ & 0.000 \\
Math test score & 0.119 & 0.119 & 0.010 & $0.044^{*}$ & $-0.034+$ \\
Math self-efficacy & 0.119 & 0.119 & 0.008 & 0.006 & 0.001 \\
\hline Panel B: Non-STEM Degree Outcome & & & & \\
Mom STEM occupation & 0.576 & 0.622 & -0.026 & -0.016 & -0.009 \\
Dad STEM occupation & 0.555 & 0.623 & -0.049 & -0.015 & -0.034 \\
Highest HS math & 0.607 & 0.64 & -0.002 & -0.004 & 0.002 \\
Highest HS science & 0.6 & 0.632 & -0.007 & -0.016 & 0.010 \\
Math test score & 0.597 & 0.635 & -0.009 & $-0.038^{* *}$ & $0.029+$ \\
Math self-efficacy & 0.597 & 0.635 & -0.007 & -0.005 & -0.001 \\
\hline
\end{tabular}

Source: Education Longitudinal Study (ELS 2002/2012)

Note: ${ }^{* *} \mathrm{p}<0.001 ; * \mathrm{p}<0.01 ;+\mathrm{p}<0.05$ 